\title{
KANDUNGAN LOGAM BERAT PADA BIJI KAKAO ASAL SULAWESI BARAT DAN TENGGARA
}

\author{
(Heavy Metals Content in Cocoa Beans from West and Southeast Sulawesi) \\ Eky Yenita Ristanti, Suprapti, Sitti Ramlah \\ Balai Besar Industri Hasil Perkebunan \\ Jl. Prof. Abdurahman Bassalamah No. 28 Makassar 90231 \\ Pos-el: eky.yristanti@gmail.com \\ (Artikel diterima 12 Juli 2016; direvisi 21 September; disetujui 15 Desember 2016)
}

\begin{abstract}
Research on heavy metals content in cocoa beans from West and Southeast Sulawesi has been done. This research aims to identify heavy metals content, which are $\mathrm{Pb}, \mathrm{Cu}, \mathrm{Cd}$ and $\mathrm{Zn}$ in cocoa beans from West and Southeast Sulawesi. Results shows that Pb content in cocoa beans from West Sulawesi is in the interval of 49,616 ppm (Mamuju) - 112,343 ppm (North Mamuju); Cu 141,362 ppm (Mamuju) - 198,04 ppm (North Mamuju); Cd 0,0494 ppm (Mamasa) - 0,7468 (Polman); Zn 193, 186 ppm (Polman) - 247,362 ppm (North Mamuju). Pb content of cocoa beans from Southeast Sulawesi is in the interval of 33,783 ppm (Kendari) - 112,912 ppm (North Kolaka); Cu 119,162 ppm (Muna) - 180,728 ppm (Kolaka); Cd 0,0769 ppm (Bombana) - 0,6676 (North Kolaka) dan Zn 29,21 ppm (Bombana) - 214,12 ppm (North Kolaka).
\end{abstract}

Keywords: heavy metals, cocoa beans, SNI 7387:2009, West Sulawesi, Southeast Sulawesi

\begin{abstract}
Abstrak. Penelitian mengenai kandungan logam berat pada biji kakao asal Sulawesi Barat dan Tenggara telah dilakukan. Penelitian ini bertujuan untuk mengetahui kandungan logam berat yaitu $\mathrm{Pb}, \mathrm{Cu}, \mathrm{Cd}$ dan Zn pada biji kakao yang berasal dari Sulawesi Barat dan Tenggara. Dari hasil penelitian, biji kakao dari Sulawesi Barat kandungan Pb dari biji kakao dari Sulawesi Barat berada pada interval 49,616 ppm (Mamuju) - 112,343 ppm (Mamuju Utara); Cu 141,362 ppm (Mamuju) - 198,04 ppm (Mamuju Utara); Cd 0,0494 ppm (Mamasa) - 0,7468 (Polman); Zn 193,186 ppm (Polman) - 247,362 ppm (Mamuju Utara). Kandungan Pb dari biji kakao dari Sulawesi Tenggara berada pada interval 33,783 ppm (Kendari) - 112,912 ppm (Kolaka Utara); Cu 119,162 ppm (Muna) - 180,728 ppm (Kolaka); Cd 0,0769 ppm (Bombana) 0,6676 (Kolaka Utara) dan Zn 29,21 ppm (Bombana) - 214,12 ppm (Kolaka Utara).
\end{abstract}

Kata Kunci: logam berat, biji kakao, SNI 7387:2009, Sulawesi Barat, Sulawesi Tenggara

\section{PENDAHULUAN}

Keamanan pangan merupakan salah satu masalah yang menjadi topik penting di dunia. Cemaran logam berat pada produk pertanian termasuk salah satu faktor yang mempengaruhi kemanan pangan, karena dapat mengakibatkan gangguan kesehatan apabila terakumulasi dalam tubuh manusia. Cemaran logam berat dapat disebabkan faktor antropogenik seperti residu pestisida dan pupuk, cemaran dari aktivitas pertambangan dan industri berat (Khan et al., 2008). Beberapa negara tujuan ekspor, yang biasanya merupakan negara maju dengan pendapatan perkapita yang tinggi, menetapkan batas kandungan logam berat seperti cadmium $(\mathrm{Cd})$ dan timbal $(\mathrm{Pb})$. Adanya persyaratan ini, telah menjadi salah satu non-trade barrier bagi negara-negara pengekspor hasil pertanian, yang pada umumnya adalah negara-negara sedang dan belum berkembang (Unnevehr, 2000; Crivelli dan Gröschl, 2012).

Gejala keracunan logam berat seperti $\mathrm{Cd}, \mathrm{Pb}, \mathrm{As}, \mathrm{Hg}, \mathrm{Zn}, \mathrm{Cu}$ dan Al ditandai dengan gangguan gastrointestinal, diare, stomatitis, tremor, hemoglobinuria yang menyebabkan feses berwarna kemerahan, ataksia (gangguan saraf), paralisis (kelumpuhan), mual dan muntah, depresi dan bahkan dapat menyebabkan pneumonia jika terhirup. Sifat dari pengaruh paparan logam berat dapat menjadi racun (akut, kronis atau sub-kronis), neurotoksik, karsinogenik, mutagenik maupun teratogenik. Kadmium bersifat racun meskipun pada konsentrasi yang sangat 
rendah. Paparan jangka panjang pada manusia dapat menyebabkan disfungsi ginjal yang ditandai dengan proteinuria tubular. Paparan cadmium yang sangat tinggi dapat menyebabkan penyakit kerusakan paruparu, cadmium pneumonitis yang disebabkan karena terhirupnya debu dan uap. Kadmium juga berhubungan dengan kerusakan tulang, antara lain osteomalacia, osteoporosis dan patah tulang spontan, peningkatan tekanan darah dan disfungsi myokardik (Duruibe et al., 2007). Oleh sebab itu, penentuan batas maksimum kandungan logam berat dalam biji kakao sangat penting untuk menghindari resiko masuknya logam berat dalam rantai makanan.

Sumber logam berat di lingkungan dapat berasal dari: faktor alamiah, pertanian, aktifitas industri, buangan rumah tangga, atmosfer dan sumber lainnya. Aktifitas seperti pertambangan dan peleburan serta pertanian telah mengakibatkan meluasnya pencemaran oleh logam berat seperti $\mathrm{Cd}$, $\mathrm{Cu}$ dan $\mathrm{Zn}$ di beberapa negara di dunia, antara lain Jepang, Indonesia dan Cina (Herawati et al., 2000). Tanaman menyerap berbagai mineral esensial dari dalam tanah untuk melengkapi siklus hidupnya. Beberapa mineral bersifat esensial bagi tanaman antara lain besi, mangan, molybdenum, tembaga, seng dan nikel. Mineral-mineral tersebut disebut juga sebagai mikronutrien, karena hanya dibutuhkan dalam jumlah kecil. Logam golongan transisi seperti perak, emas dan kobalt, serta logam golongan non-transisi seperti aluminium, telah terbukti menstimulasi pertumbuhan tanaman, tetapi tidak dikategorikan esensial. Selain itu, tanaman juga menyerap elemenelemen yang tidak memiliki fungsi biologi, bahkan beberapa diketahui beracun pada konsentrasi rendah sekalipun. Diantaranya adalah arsenik (As), kadmium (Cd), kromium $(\mathrm{Cr})$, merkuri $(\mathrm{Hg})$ dan timbal $(\mathrm{Pb})$ (PeraltaVidea et al., 2009).

Pupuk anoganik dan organik merupakan sumber logam berat pada tanah pertanian, Pupuk fosfat $(P)$ fosfat mengandung sejumlah kecil kontaminan logam berat yang merupakan konstituen minor dari batuan fosfat (Phospate Rocks,
PR). Transfer logam berat dari batuan fosfat ke pupuk superfosfat tergantung dari metode yang digunakan untuk membuat pupuk superfosfat. Superfosfat biasa (single) diproduksi dengan cara mereaksikan $\mathrm{H}_{2} \mathrm{SO}_{4}$ dengan batuan fosfat. Produk yang dihasilkan akan mengandung semua logam berat penyusun batuan fosfat. Pupuk triple superfosfat (TSP) mengandung 60-70\% kadmium (Cd) yang ditemukan pada batuan fosfat. Pupuk kandang dan lumpur limbah (biosolids) merupakan pupuk organik yang banyak digunakan, juga mengandung kontaminan logam berat. Logam berat dalam biosolids dapat ditemukan dalam bentuk anorganik atau organo-kompleks, yang dapat mempengaruhi reaksi kimia dalam tanah. Logam berat dapat terakumulasi dalam tanah apabila pemakaian pupuk berulang (Mortvedt, 1996).

Pertambangan dan pemurnian bijih yang meliputi aktifitas pengkonsentrasian bijih dan pembuangan tailing serta air limbah, dapat menyebabkan kontaminasi logam berat ke lingkungan sekitar. Kadar logam berat di sekitar area pertambangan cenderung tinggi, karena buangan dan resapan limbah pertambangan akan terakumulasi pada lahan pertanian, tanaman, serta aliran sungai. Studi yang dilakukan oleh Jung (2001) menyebutkan bahwa penambangan emas (Au)-perak (Ag) menyebabkan tanah dan air di sekitar wilayah pertambangan memiliki konsentrasi $\mathrm{Cd}, \mathrm{Cu}, \mathrm{Pb}$ dan $\mathrm{Zn}$ yang tinggi, yang berasal dari tailing. $\mathrm{Cd}, \mathrm{Cu}, \mathrm{Pb}$ dan $\mathrm{Zn}$ merupakan mineral ikutan yang lazim pada penambangan emas. Cakupan dan tingkat kontaminasi logam berat di sekitar tambang bervariasi tergantung pada karakteristik geokimia dan mineralisasi tailing.

Tanaman kakao (Theobroma cacao) di Indonesia mulai banyak dibudayakan di Pulau Sulawesi sejak akhir 1970-an, yang dipicu oleh menurunnya produksi kakao negara-negara Afrika Barat sehingga berakibat pada melonjaknya harga kakao dunia. Perluasan wilayah perkebunan kakao di Sulawesi mencapai 30 kali lipat pada periode 1980 hingga 1994 dimana pada tahun 1980, luas areal perkebunan kakao hanya 13.125 ha dan menjadi 389.946 ha 
pada 1994 (Akiyama dan Nishio, 1996). Pertanian kakao di Indonesia menerapkan sistem pemupukan dengan menggunakan pupuk anorganik seperti misalnya pupuk ZA dan TSP (Anonim, 2015). Perluasan area penanaman kakao tentu mengakibatkan semakin meluasnya pemakaian pupuk, ditambah kondisi geografis yang memiliki potensi pertambangan, menyebabkan kemungkinan terjadinya kontaminasi logam berat terhadap tanah dan air yang digunakan untuk budidaya tanaman kakao, sehingga hal ini memungkinkan tingginya kandungan logam berat pada biji kakao yang berasal dari Sulawesi.

Di Indonesia, batas maksimum kandungan logam berat dalam pangan untuk kategori logam $\mathrm{As}, \mathrm{Cd}, \mathrm{Hg}$, Sn dan $\mathrm{Pb}$ telah ditetapkan melalui SNI No. 7387:2009, termasuk untuk kembang gula/permen dan cokelat, serta cokelat bubuk. Batas kandungan $\mathrm{Cd}$ untuk cokelat dan produk kakao menurut SNI No. 7387:2009 adalah 0,5 $\mathrm{mg} / \mathrm{kg}$. Batas kadar Hg pada cokelat bubuk adalah sebesar $0,03 \mathrm{mg} / \mathrm{kg}$, sedangkan untuk kadar arsen dibatasi sampai $1,0 \mathrm{mg} /$ kg (BSN, 2009). Untuk pasar Uni Eropa, yang merupakan negara pengkonsumsi cokelat terbesar di dunia, mulai tahun 2019 akan memberlakukan batas kadmium yang diperbolehkan pada kakao dan produk turunanya, sebagaimana ditampilkan pada tabel 1 berikut:

daerah di Provinsi Sulawesi Barat dan Tenggara memiliki potensi pertambangan dan di beberapa daerah.

Tabel 1. Kadar kadmium yang diijinkan pada kakao dan produk turunannya

\begin{tabular}{lc}
\hline \multicolumn{1}{c}{ Spesifikasi Cokelat dan Produk Cokelat } & $\begin{array}{c}\text { Kadar Kadmium } \\
\text { yang Dijinkan } \\
\text { (ppm) }\end{array}$ \\
\hline Milk chocolate dengan total kandungan padatan kakao kering $<30 \%$ & 0,10 \\
$\begin{array}{l}\text { Cokelat dengan total kandungan padatan kakao kering }<50 \% ; \\
\text { milk chocolate dengan total kandungan padatan kakao kering } \geq 30 \%\end{array}$ & 0,30 \\
$\begin{array}{l}\text { Cokelat dengan total kandungan padatan kakao kering }>50 \% \\
\text { Cokelat bubuk yang dijual kepada konsumer terakhir atau sebagai } \\
\text { bahan yang ditambahkan pada minuman cokelat bubuk dijual pada } \\
\text { konsumer terakhir. }\end{array}$ & 0,80 \\
\hline
\end{tabular}

Untuk biji kakao, importir Uni Eropa mempertimbangkan akan memberlakukan persyaratan kadar cadmium maksimal $<0,5$ ppm. Hal ini mengacu pada Jerman yang telah memberlakukan aturan $<0,3 \mathrm{ppm}$ pada cokelat. Biji kakao dengan kandungan sampai dengan 0,8 ppm masih akan diterima, tetapi diatas 0,8 ppm, akan dilihat kandungan kakao pada cokelat tersebut. Jika kadarnya diatas 1 ppm, maka pembuat cokelat harus mencampur dengan biji kakao yang memiliki kadar cadmium lebih rendah (CBI, 2016).

Penelitian ini bertujuan untuk mengetahui kadar logam berat yaitu $\mathrm{Pb}, \mathrm{Cu}, \mathrm{Cd}$ dan $\mathrm{Zn}$ pada biiji kakao asal Sulawesi Barat dan Tenggara. $\mathrm{Pb}, \mathrm{Cu}, \mathrm{Cd}$ dan $\mathrm{Zn}$ merupakan mineral ikutan pada penambangan emas. Beberapa juga telah beroperasi penambangan emas, seperti daerah Kolaka dan Bombana. Belum banyak penelitian yang mengulas mengenai kandungan logam berat pada biji kakao asal Indonesia, karena selama ini biji kakao asal Indonesia kebanyakan hanya digunakan sebagai pencampur, sehingga meskipun kandungan logam beratnya tinggi, apabila dicampur dengan biji kakao dari negara lain yang tidak tinggi, maka kandungan logam berat pada produk akhir akan turun.

\section{METODE PENELITIAN}

\section{Bahan dan Peralatan}

Bahan yang digunakan pada penelitian ini adalah biji kakao jenis lindak yang berasal dari 5 Kabupaten di Sulawesi Barat, yaitu Kabupaten Polman, Kabupaten Majene, Kabupaten Mamasa, Kabupaten Mamuju 
dan Kabupaten Mamuju Utara; dan 7 Kabupaten di Sulawesi Tenggara, yaitu Kota Kendari, Kabupaten Muna, Kabupaten Konawe, Kabupaten Konawe Selatan, Kabupaten Bombana, Kabupaten Kolaka dan Kabupaten Kolaka Utara.

Bahan kimia yang digunakan dalam penelitian ini antara lain $\mathrm{HNO}_{3}, \mathrm{HCl}, \mathrm{H}_{2} \mathrm{O}_{2}$ $30 \%$ serta larutan standar $\mathrm{Cd}, \mathrm{Pb}, \mathrm{Cu}$ dan $\mathrm{Zn}$.

Peralatan yang digunakan pada penelitian ini antara lain neraca analitik, labu ukur, cawan silica, tanur, oven dengan ventilasi, pemanas, labu Kjedahl dan spektrofotometer serapan atom Perkin Elmer tipe AA700.

\section{Metode Pengambilan Sampel}

Pengambilan sampel biji kakao dilakukan secara purposive melalui penetapan kriteria spesifik terhadap daerahdaerah penghasil kakao di Sulawesi Barat dan Tenggara. Kriteria tersebut dapat berupa adanya sentra penghasil kakao dan merupakan potensi terbesar diantara daerah penghasil kakao dalam suatu kabupaten, kecamatan atau desa.

\section{Penetapan dan Analisis Sampel}

Provinsi Sulawesi Barat memiliki lima Kabupaten, dimana kelima Kabupaten tersebut juga memiliki potensi kakao terbesar, sehingga semua Kabupaten tersebut ditetapkan sebagai wilayah target sampling, yaitu: Kab. Polman (16 Kecamatan), Kab. Majene (8 Kecamatan), Kab. Mamasa (17 Kecamatan), Kab. Mamuju(10 Kecamatan) dan Kab. Mamuju Utara (12 Kec.) Sedangkan Provinsi Sulawesi Tenggara memilliki 10 Kota/ Kabupaten, namun hanya tujuh diantaranya yang memiliki potensi kakao terbesar, yaitu: Kota kendari (10 Kecamatan), Kab. Muna (33 Kecamatan), Kab. Konawe (30 Kecamatan), Kab. Konawe Selatan (22 Kecamatan), Kab. Bombana (21 Kecamatan), Kab. Kolaka(12 Kecamatan) dan Kab. Kolaka Utara (15 Kecamatan). Sampel biji kakao diambil dari setiap pedagang pengumpul di desa dari beberapa Kecamatan untuk setiap Kota/ Kabupaten.
Analisa kadar logam $\mathrm{Cd}, \mathrm{Pb}, \mathrm{Cu}$, dan Zn pada sampel biji kakao mengacu pada SNI 2323:2008 mengenai Biji Kakao (Lampiran $\mathrm{E}$ untuk penentuan cemaran logam $\mathrm{Cd}$, Lampiran $\mathrm{F}$ untuk untuk penetapan kadar $\mathrm{Cu}$ dan Zn, dan Lampiran G untuk penetapan kadar $\mathrm{Pb}$ )

\section{HASIL DAN PEMBAHASAN}

Hasil pengujian kadar $\mathrm{Pb}, \mathrm{Cu}, \mathrm{Cd}$, dan $\mathrm{Zn}$ dari biji kakao asal Provinsi Sulawesi Barat ditampilkan pada Gambar 1 berikut:

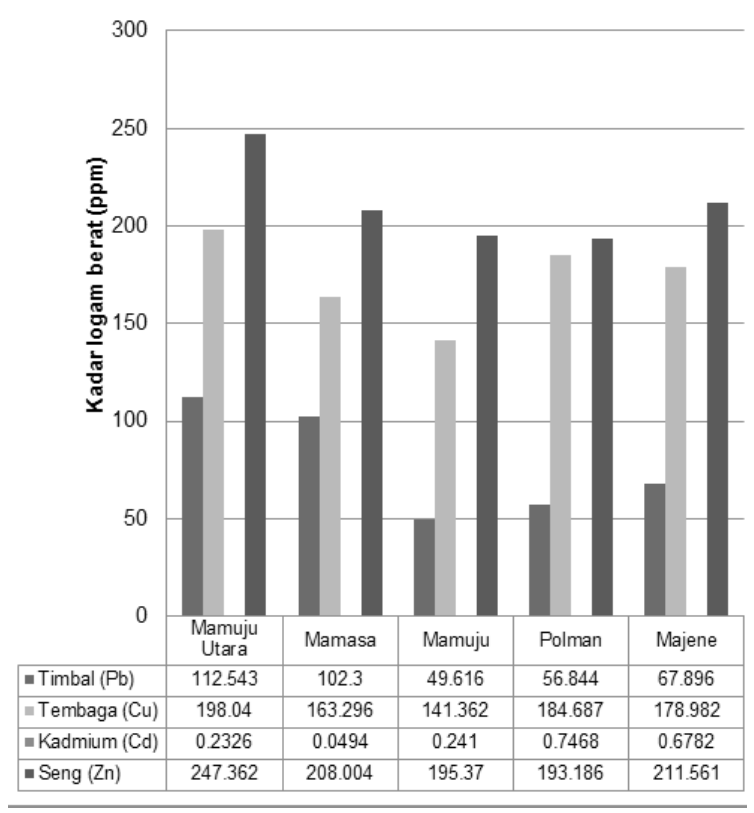

Gambar 1. Hasil Analisa Kandungan Logam Berat $\mathrm{Pb}, \mathrm{Cu}, \mathrm{Cd}$ dan $\mathrm{Zn}$ pada biji kakao dari Sulawesi Barat

Hasil analisa menunjukkan bahwa Kabupaten Mamasa Utara memiliki kandungan $\mathrm{Pb}, \mathrm{Cu}$ dan $\mathrm{Zn}$ yang lebih tinggi dibandingkan dengan Kabupaten Mamasa, Mamuju, Polman dan Majene.

Secara keseluruhan, semua Kabupaten di Provinsi Sulawesi Barat yang diambil sampel biji kakaonya, memiliki kadar $\mathrm{Pb}, \mathrm{Cu}$, dan $\mathrm{Zn}$ yang sangat tinggi. Meskipun dalam SNI 2323:2008, yang mengatur standar mutu biji kakao, tidak ditentukan batas maksimal kadar $\mathrm{Pb}, \mathrm{Cu}$ dan $\mathrm{Zn}$ dalam biji kakao, namun pada SNI 7387:2009 yang mengacu pada SK Dirjen POM 1989, 
ditetapkan bahwa batas maksimal kadar $\mathrm{Pb}$ dalam kembang gula dan cokelat hanya sebesar $2 \mathrm{ppm}$. Dengan kadar $\mathrm{Pb}$ yang mencapai 112,543 ppm pada biji kakao asal Mamuju Utara dan 102,3 ppm pada biji kakao asal Mamasa, akan sulit dicapai produk akhir yang memiliki kadar $\mathrm{Pb}<2 \mathrm{ppm}$.

Hasil analisa Cd pada biji kakao asal Sulawesi Barat menunjukkan bahwa Kabupaten Mamasa memiliki kadar Cd yang terendah, yaitu sebesar 0,0494 ppm. Sedangkan biji kakao dari Kabupaten Majene dan Polman, mengandung kadmium > 0,5 ppm. Biji kakao dari Kabupaten Mamuju Utara dan Mamuju memiliki kadar kadmium secara berturtut-turut 0,2326 ppm dan 0,241 ppm. Terkait akan diberlakukannya persyaratan batas kadar maksimal Cd pada biji kakao untuk ekspor ke Uni Eropa, maka biji kakao yang berasal dari Kabupaten Mamasa, Mamuju Utara dan Mamuju masih dapat memenuhi persyaratan tersebut. Sedangkan biji kakao dari Kabupaten Majene dan Polman harus diperiksa dulu kadar kakaonya, terkait aturan fleksibilitas biji kakao dengan kadar cadmium > dari 0,8 ppm.

Hasil pengujian kadar $\mathrm{Pb}, \mathrm{Cu}, \mathrm{Cd}$, dan Zn dari biji kakao asal Sulawesi Tenggara ditampilkan pada Gambar 2 berikut:

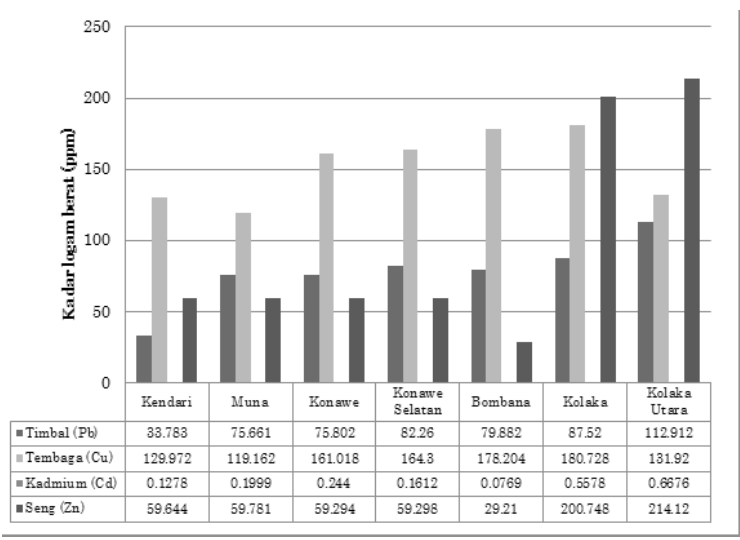

Gambar 2. Hasil Analisa Kandungan Logam

Berat $\mathrm{Pb}, \mathrm{Cu}, \mathrm{Cd}$ dan $\mathrm{Zn}$ pada biji kakao dari Sulawesi Tenggara

Hasil analisa kadar $\mathrm{Pb}$ dari ketujuh kabupaten di Sulawesi Tenggara menunjukkan bahwa kadar $\mathrm{Pb}$ yang tertinggi adalah pada biji kakao dari Kabupaten Kolaka Utara, yaitu 112,912 ppm. Kadar Pb dari Kota Kendari adalah yang terendah, yaitu 33,783 ppm. Biji kakao dari Kabupaten Muna, Konawe, Konawe Selatan, Bombana dan Kolaka berada pada kisaran 75,661$87,52 \mathrm{ppm}$. Kadar $\mathrm{Pb}$ yang tertinggi di Provinsi Sulawesi Barat dan Sulawesi Tenggara berada pada kisaran yang sama, yaitu pada nilai sekitar 112 ppm, sedangkan untuk kadar $\mathrm{Pb}$ terendah, biji kakao dari Kota Kendari, Sulawesi Tenggara memiliki nilai yang lebih rendah, yaitu 33,783 ppm dibandingkan kadar $\mathrm{Pb}$ dari Mamuju, yaitu pada 49,616 ppm.

Hasil analisa Cu pada biji kakao dari Sulawesi Tenggara didapatkan berada pada kisaran 119,162 ppm-180,728 ppm, dengan kadar Cu tertinggi diperoleh pada biji kakao dari Kabupaten Kolaka. Kabupaten Bombana juga memiliki kadar Cu yang tinggi, yaitu sebesar 178,204 ppm. Hasil analisa $\mathrm{Cu}$ secara umum dari Provinsi Sulawesi Tenggara memiliki interval nilai yang lebih besar daripada kadar Cu di Sulawesi Barat yang berada pada interval 141,362 -198,04 ppm.

Kadar kadmium (Cd) dalam biji kakao yang berasal dari Sulawesi Tenggara diperoleh hasil terendah pada Kabupaten Bombana, yaitu sebesar 0,0769 ppm dan yang tertinggi pada Kabupaten Kolaka Utara, yaitu sebesar 0,6676 ppm. Kadar Cd pada biji kakao dari Kota Kendari, Kabupaten Muna, Kabupaten Konawe, kabupaten Konawe Selatan dan Kabupaten Kolaka berada pada kisaran 0,1999-0, 5578 ppm. Secara umum, biji kakao dari Sulawesi Tenggara masih masuk kategori aman terkait persayaratan mengenai batas kadar cadmium pada biji kakao.

Hasil analisa kadar Zn pada biji kakao dari Sulawesi Tenggara diperolah hasil yang tertinggi pada biji kakao yang berasal dari Kolaka Utara, yaitu sebesar 214,12 ppm, sedangkan kadar $\mathrm{Zn}$ yang terendah adalah biji kakao dari Kabupaten Bombana, yaitu sebesar 29,21 ppm. Seng (Zn) dibutuhkan untuk pertumbuhan tanaman dan manusia dalam jumlah tertentu. Namun, dalam 
paparan senk jumlah yang berlebih dan dalam jangka waktu lama, dapat menyebabkan gangguan pada otak, saluran pernafasan, saluran pencernaan, dan prostat. Kelebihan seng juga menyebabkan kekurangan $\mathrm{Cu}$ (Plum et al, 2010).

Rehman dan Husnain (2012 melakukan analisa kandungan $\mathrm{Pb}$ dan $\mathrm{Cd}$ pada produk cokelat, karena komposisi kimia pada biji kakao, memungkinkan $\mathrm{Pb}$ dan $\mathrm{Cd}$ terikat secara kuat. Kadar Kadmium merupakan parameter yang sangat diperhatikan dalam perdagangan internasional biji kakao, karena Cd bersifat racun, meskipun dalam jumlah kecil. Bertoldi et al (2016) melakukan kajian fingerprint multielemental dan ketertelusuran geografis biji kakao dan produk turunannya. Dari hasil penelitian Bertoldi, diketahui bahwa rata-rata kadar kadmium tertinggi ditemukan pada biji kakao asal Amerika Selatan $(1,388 \pm 1,089 \mathrm{ppm})$ sedangkan yang terendah adalah biji kakao dari Afrika Barat $(0,926 \pm 0,418 \mathrm{ppm})$. Sedangkan rata-rata kadar kadmium pada biji kakao asal Asia berada pada kisaran 0,328 $\pm 0,176 \mathrm{ppm}$.

Biji kakao, lemak kakao, bubuk cokelat dan produk cokelat kemungkinan mengandung ikutan logam berat yang dapat mempengaruhi kesehatan consumer, terutama anak-anak. Logam $\mathrm{Pb}$ biasaya terakumulasi pada kulit biji, yang dapat dihilangkan selama proses winnowing (deshelling). Sedangkan Cd biasany terdapat dalam jumlah yang lebih besar pada produk kakao, yang dapat juga diperoleh selama proses manufaktur (Yanus, et al., 2014).

Akumulasi tembaga $(\mathrm{Cu})$ pada biji kakao diasosikan dengan pemakaian fungisida berbasis-Cu. $\mathrm{Cu}$ masuk ke dalam biji kakao melalui pengambilan dan trasnlokasi Cu dari tanah, serta permeasi $\mathrm{Cu}$ pada kutikula kulit buah setetlah penggunaan fungisida. Aikpokpodion (2013) menyebutkan bahwa penggunaan fungisida berbasis $\mathrm{Cu}$ pada kulit buah kakao memberi kontribusi terhadap kandungan Cu pada biji kakao.

\section{SIMPULAN}

Dari hasil penelitian yang dilakukan, dapat disimpulkan bahwa kandungan $\mathrm{Pb}$ dari biji kakao dari Sulawesi Barat berada pada interval 49,616 ppm (Mamuju) - 112,343 ppm (Mamuju Utara); Cu 141,362 ppm (Mamuju) - 198,04 ppm (Mamuju Utara); Cd 0,0494 ppm (Mamasa) - 0,7468 (Polman); Zn 193,186 ppm (Polman) - 247,362 ppm (Mamuju Utara). Kandungan $\mathrm{Pb}$ dari biji kakao dari Sulawesi Tenggara berada pada interval 33,783 ppm (Kendari) - 112,912 ppm (Kolaka Utara); Cu 119,162 ppm (Muna) 180,728 ppm (Kolaka); Cd 0,0769 ppm (Bombana) - 0,6676 (Kolaka Utara) dan Zn 29,21 ppm (Bombana) - 214,12 ppm (Kolaka Utara).

\section{DAFTAR PUSTAKA}

Aipokpodion, P. E., Lajidu, L. dan Aiyesanmi, A. F. (2013). Impact of Cu-based fungicide on copper residue and mineral elements distribution in cocoa beans and pods. World Journal of Agricultural Sciences. 9(1): 10-16

Akiyama, T. dan Nishio,A., (1996). Indonesia's Cocoa Boom: Hands-Off Policy Encourages Smallholder Dynamism. Policy Research Working Paper 1580, The World Bank, Washington, 44pp.

Anonim, (2015), Budidaya kakao. Artikel: diakses pada tanggal 27 September 2015.

http://www.produknaturalnusantara. com/panduan-teknis-budidayapertanian/panduan-cara-budidayakakaol

Bertoldi, D., Barbero,A., Camin, F., Caligiani,A. dan Larcher, R. (2016). Multielemental fingerprint and geographic traceability of Theobroma cacao beans and cocoa products. Food Control. 65. 46-53

BSN, (2009), SNI 7387:2009 Batas maksimum cemaran logam berat dalam pangan.

Crivelli, P dan Gröschl, J., (2012). The Impact of Sanitary and Phytosanitary Measures on Market Entry and Trade Flows, IFO Working Paper, 136.

Duruibe, J.O., Ogwuegbu, M.O.C dan Egwurugwu, J. N. (2007). Heavy metal pollution and human biotoxic effects. 
Int. J. of Physical Sciences. Vol. 2 (5). pp. 112-118.

Gill, M., (2014). Heavy metal stress in plants : a review, International Journal 2 (6), 1043-1055.

Herawati, N., Suzuki, S., Hayashi, K., Rivai, I.F. and Koyama, H. (2000): Cadmium, copper and zinc levels in rice and soil of Japan, Indonesia and China by soil type. Bull. Environ. Contam. Toxicol. 64, 33-39.

Jarup, L. (2003). Hazards of heavy metal contamination. British Medical Bulletin, 68(1), 167-182.

Jung, M. C. (2001). Heavy metal contamination of soils and waters in and around the Imcheon $\mathrm{Au}$ - Ag mine , Korea, 16, 1369-1375.

Khan, S., Cao, Q., Zheng, Y. M., Huang, Y. Z., \& Zhu, Y. G. (2008). Health risks of heavy metals in contaminated soils and food crops irrigated with wastewater in Beijing, China. Environmental Pollution (Barking, Essex : 1987), 152(3), 68692.

Mortvedt, J.J., (1996). Heavy metal contaminant in inorganic and organic fertilizer. Fertilizer Research. 43, 5561.
Peralta-Videa, J. R., Lopez, M. L., Narayan, M., Saupe, G., \& Gardea-Torresdey, J. (2009). The biochemistry of environmental heavy metal uptake by plants: implications for the food chain. The International Journal of Biochemistry \& Cell Biology, 41(8-9), 1665-1677.

Plum, L.M., Rink, L., dan Haase, H. (2010). The Essential Toxin: Impact of Zinc on Human Health. Review. Int. J. Environ. Res. Public Health 2010, 7, 1342-1365. doi:10.3390/ijerph7041342

Rehman, S. dan Husnain, S.H. (2012). Assessment of trace metal contents in chocolate samples by Atomic Adsorption Spectroscopy. J. of Trace Element Analys. Vol. 1, No. 1, pp. 1-11 doi:10.7726/jtea.2012.1001

Unnevehr, L. J. (2000). Food safety issues and fresh food product exports from LDCs, 23, 231-240.

Yanus, R. L., Sela, H., Borojovich, E. J. C., Zakon, Y., Saphier, M., Nikolski, A., et al. (2014). Trace elements in cocoa solids and chocolate: an ICPMS study. Talanta,119, 1-4. 